\title{
Synthesis and Enzymatic Incorporation of a Responsive Ribonucleoside Probe That Enables Quantitative Detection of Metallo-Base Pairs
}

\author{
Sudeshna Manna and Seergazhi G. Srivatsan*
}

Department of Chemistry, Indian Institute of Science Education and Research (IISER), Pune Dr. Homi Bhabha Road, Pune 411008, India. *E-mail: srivatsan@iiserpune.ac.in

\section{Supporting Information}

\begin{tabular}{|c|c|}
\hline Content & Page \# \\
\hline 1. Materials & S2 \\
\hline 2. Instrumentation & S2 \\
\hline 3. Synthesis of 5-(5-methoxybenzofuran)-uridine and corresponding triphosphate. & S3 \\
\hline $\begin{array}{l}\text { 4. Photophysical analysis of 5-methoxybenzofuran-modified uridine analogue } \mathbf{1} \text { in different } \\
\text { solvents. }\end{array}$ & S4 \\
\hline $\begin{array}{l}\text { Figure S1. Relative quantum yield versus } E_{T}(30) \text { plot for nucleoside } \mathbf{1} \text { and other heterocycle- } \\
\text { conjugated nucleoside probes. }\end{array}$ & S5 \\
\hline 5. Transcription reaction with $\alpha{ }^{-32} \mathrm{P}$ ATP. & S5 \\
\hline Figure S2. Phosphor image of PAGE resolved transcription products. & S6 \\
\hline 6. Large-scale transcription. & S6 \\
\hline Figure S3. HPLC chromatogram and MALDI-TOF spectrum of PAGE purified transcript 4. & S7 \\
\hline 7. MALDI-TOF mass analysis of transcript 4 & S7 \\
\hline 8. Enzymatic digestion of transcript 4. & S7 \\
\hline $\begin{array}{l}\text { Figure S4. HPLC chromatogram of ribonucleosides obtained from enzymatic digestion of } \\
\text { transcript } 4 .\end{array}$ & S8 \\
\hline Table S1. MALDI-TOF mass analysis of HPLC fractions of transcript 4 digest. & S8 \\
\hline $\begin{array}{l}\text { 9. Steady-state fluorescence studies of transcript } 4 \text { and its duplexes in the presence and absence } \\
\text { of metal ions. }\end{array}$ & S8 \\
\hline $\begin{array}{l}\text { Figure S5. Fluorescence intensity of transcript } \mathbf{4} \text { and its duplexes with perfect complementary } \\
\text { and mismatched DNA and RNA ONs as respective emission maximum. }\end{array}$ & S9 \\
\hline 10. Circular dichroism (CD) studies. & S9 \\
\hline $\begin{array}{l}\text { Figure S6. CD spectra of control DNA-DNA, modified DNA-RNA and modified RNA-RNA } \\
\text { duplexes. }\end{array}$ & S10 \\
\hline $\begin{array}{l}\text { Figure S7. Fluorescence intensity of free nucleoside 1, transcript } 4 \text { and its duplexes with } \\
\text { perfect complementary and mismatched DNA and RNA ONs at respective emission } \\
\text { maximum. }\end{array}$ & S10 \\
\hline $\begin{array}{l}\text { Figure S8. Fluorescence intensity of duplexes } \mathbf{4 \cdot 8} \text { containing dT-1 mismatch and } \mathbf{4} \cdot \mathbf{1 0} \\
\text { containing U-1 mismatch at } 440 \mathrm{~nm} \text {. }\end{array}$ & S11 \\
\hline 11. Fluorescence binding assay. & S11 \\
\hline $\begin{array}{l}\text { Figure S9. Emission spectra of fluorescently labeled duplexes } 4 \cdot 8 \text { and } 4 \cdot 10 \text { containing } \\
\text { increasing concentration of } \mathrm{Hg}^{2+} \text { ions. }\end{array}$ & S12 \\
\hline 12. Thermal melting analysis of ON duplexes. & S12 \\
\hline $\begin{array}{l}\text { Figure S10. Representative UV-thermal melting profile of duplexes } \mathbf{3} \cdot \mathbf{8}, \mathbf{4} \cdot \mathbf{8} \text { with dT-U or dT- } \\
\mathbf{1} \text { mismatch and } \mathbf{3 \cdot 1 0}, \mathbf{4} \cdot \mathbf{1 0} \text { with } \mathrm{U}-\mathrm{U} \text { or } \mathrm{U}-\mathbf{1} \text { mismatch in the presence or absence of } \mathrm{Hg}^{2+} \text { ions. }\end{array}$ & S13 \\
\hline Table S2. $T_{m}$ values of control and modified duplexes. & S13 \\
\hline 13. ${ }^{1} \mathrm{H}$ NMR analysis of ON duplexes. & S14 \\
\hline $\begin{array}{l}\text { Figure S11. Partial }{ }^{1} \mathrm{H} \text { NMR spectra of duplexes } 4 \cdot 8 \text { with dT-1 mismatch and } 4 \cdot 10 \text { with U-1 } \\
\text { mismatch in the absence and presence of } \mathrm{Hg}^{2+} \text { ion. }\end{array}$ & S14 \\
\hline 14. NMR Spectra & S15 \\
\hline 15. References & S18 \\
\hline
\end{tabular}


1. Materials. $N, N, N^{\prime}, N^{\prime}$-tetramethylethylenediamine, $n$-butyllithium, tributyltin chloride, bis(triphenylphosphine)-palladium(II) dichloride and all reagents (Bio-Ultra grade) used for buffer preparation were purchased from Sigma-Aldrich. 5-Methoxybenzofuran (1a) was synthesized following a previously reported procedure. ${ }^{\mathrm{S} 1}$ 5-Iodouridine (1c) was synthesized following the previously established method. ${ }^{\mathrm{S} 2} \mathrm{CoCl}_{2} \cdot 6 \mathrm{H}_{2} \mathrm{O}, \mathrm{FeCl}_{2} \cdot 4 \mathrm{H}_{2} \mathrm{O}, \mathrm{CuSO}_{4}, \mathrm{ZnCl}_{2}$, $\mathrm{NiCl}_{2} \cdot 6 \mathrm{H}_{2} \mathrm{O}, \mathrm{PbCl}_{2}, \mathrm{CdCl}_{2} \cdot 2.5 \mathrm{H}_{2} \mathrm{O}, \mathrm{MnCl}_{2}, \mathrm{CaCl}_{2} \cdot 2 \mathrm{H}_{2} \mathrm{O}, \mathrm{MgCl}_{2} \cdot 6 \mathrm{H}_{2} \mathrm{O}$ and $\mathrm{Hg}\left(\mathrm{ClO}_{4}\right)_{2} \cdot 6 \mathrm{H}_{2} \mathrm{O}$ were purchased from either Sigma-Aldrich or Alfa Aesar. T7 RNA polymerase, ribonuclease inhibitor (RiboLock), NTPs, RNase A and RNase T1 were procured from Fermentas, Thermo Fisher Scientific. Calf intestinal alkaline phosphatase (CIP) and snake venom phosphodiesterase I were acquired from Invitrogen and Sigma-Aldrich, respectively. $\mathrm{POCl}_{3}$ was purchased from Acros Organic and was freshly distilled before use. Radiolabeled $\alpha_{-}{ }^{32} \mathrm{P}$ ATP $(2000 \mathrm{Ci} / \mathrm{mmol})$ was obtained from the Board of Radiation and Isotope Technology, Government of India. DNA ONs 5, 6, 7, 8 and 11 were purchased from Integrated DNA Technology. RNA ONs 9 and $\mathbf{1 0}$ were purchased from Dharmacon RNAi Technologies, deprotected according to the provider's procedure. All custom DNA and RNA ONs were purified by denaturing polyacrylamide gel, desalted on Sep-Pak Classic C18 cartridges (Waters Corporation). Autoclaved Millipore water was used in all biophysical analysis.

2. Instrumentation. Mass analysis was performed either on an Applied Biosystems 4800 Plus MALDI TOF/TOF analyzer or on Water Synapt G2 High Definition mass spectrometer. HPLC analysis was done using Agilent Technologies 1260 Infinity HPLC. Reverse-phase flash chromatographic (C18 RediSepRf column) purifications were carried out using Teledyne ISCO, Combi Flash Rf. Absorption spectra were recorded on a Shimadzu UV-2600 spectrophotometer. Steady-state fluorescence spectra were recorded on a Fluoromax-4 spectrophotometer. UV-thermal melting analysis of ONs was conducted on Cary 300 Bio UV-Vis spectrophotometer. CD analysis was performed on a JASCO J-815 CD spectrometer. NMR spectra of small molecules were recorded on a Bruker AVANCE III HD ASCEND 400 $\mathrm{MHz}$ spectrometer and processed using Mnova software from Mestrelab Research. NMR spectra of ON duplexes were recorded on a Bruker AVANCE III HD ASCEND $600 \mathrm{MHz}$ spectrometer equipped with $\mathrm{BB}(\mathrm{F})$ Double Channel Probe and processed using Bruker TopSpin Software. 


\section{Synthesis of 5-(5-methoxybenzofuran)-uridine and corresponding triphosphate.}

Tributyl(5-methoxybenzofuran-2-yl)stannane (1b): TMEDA (0.58 g, 5.00 mmol, 1.2 equiv) was added to a solution of 5-methoxybenzofuran (1a) (0.62 g, $4.18 \mathrm{mmol}, 1.0$ equiv) in dry THF $(20 \mathrm{ml})$ and the mixture was allowed to stir for $30 \mathrm{~min}$ at $-78{ }^{\circ} \mathrm{C}$. $n$-BuLi $(2.50$ $\mathrm{ml}, 2 \mathrm{M}$ solution in hexane, $5.00 \mathrm{mmol}, 1.2$ equiv) was added dropwise to it at $-78{ }^{\circ} \mathrm{C}$ and reaction was brought to room temperature over a period of $2 \mathrm{~h}$. The reaction mixture was again cooled to $-78{ }^{\circ} \mathrm{C}$ and $n-\mathrm{Bu}_{3} \mathrm{SnCl}(1.35 \mathrm{ml}, 5.00 \mathrm{mmol}, 1.2$ equiv) was added dropwise to it. The reaction mixture was stirred for $1 \mathrm{~h}$. The reaction was quenched with ammonium chloride solution $(25 \mathrm{ml})$ and extracted two times with diethyl ether $(2 \times 25 \mathrm{ml})$. Organic layer was dried over sodium sulphate and evaporated. The resulting oily residue was purified by flash column chromatography (petroleum ether) to afford $\mathbf{1 b}$ as a clear oil (1.27 g, 70\%). TLC (10\% EtOAc in petroleum ether) $R_{\mathrm{f}}=0.7 ;{ }^{1} \mathrm{H}$ NMR $\left(400 \mathrm{MHz}, \mathrm{CDCl}_{3}\right.$ containing $0.03 \%$ (v/v) TMS): $\delta(\mathrm{ppm}) 7.39(\mathrm{~d}, J=9.2 \mathrm{~Hz}, 1 \mathrm{H}), 7.03(\mathrm{~d}, J=2.4 \mathrm{~Hz}, 1 \mathrm{H}), 6.86-6.83(\mathrm{~m}, 2 \mathrm{H})$, $3.85(\mathrm{~s}, 3 \mathrm{H}), 1.64-1.57(\mathrm{~m}, 6 \mathrm{H}), 1.41-1.32(\mathrm{~m}, 6 \mathrm{H}), 1.24-1.07(\mathrm{~m}, 6 \mathrm{H}), 0.91(\mathrm{t}, J=7.4 \mathrm{~Hz}$, 9H), 0.01 (s, TMS); ${ }^{13} \mathrm{C}$ NMR (100 MHz, $\mathrm{CDCl}_{3}$ ): $\delta$ (ppm) 166.6, 155.6, 153.9, 128.7, 118.2, 112.2, 111.4, 102.7, 56.1, 29.1, 27.3, 13.8, 10.3; HRMS (m/z) Calculated for $\mathrm{C}_{21} \mathrm{H}_{35} \mathrm{O}_{2} \mathrm{Sn}$ $[\mathrm{M}+\mathrm{H}]^{+}=439.1659$, found $=439.1648$.

5-(5-methoxybenzofuran)-uridine (1): A mixture of 5-iodouridine (1c) $)^{\mathrm{S} 2}(0.25 \mathrm{~g}, 0.67$ mmol, 1 equiv) and bis(triphenylphosphine)-palladium(II) chloride (0.02 g, 0.034 mmol, 0.05 equiv) and tributyl(5-fluorobenzofuran-2-yl)stannane (0.73 g, $1.67 \mathrm{mmol}, 2.5$ equiv) was dissolved in degassed anhydrous dioxane $(8 \mathrm{ml})$. The mixture was heated at $90{ }^{\circ} \mathrm{C}$ for $2 \mathrm{~h}$ under $\mathrm{N}_{2}$ atmosphere and filtered through celite pad. The celite pad was washed with methanol $(2 \times 15 \mathrm{ml})$. The filtrate was evaporated and resulting residue was purified by reverse phase column chromatography (50\% methanol in water) to afford product $\mathbf{1}$ as a white solid $(0.17 \mathrm{~g}, 65 \%)$. TLC (15\% methanol in DCM) $R_{\mathrm{f}}=0.40 ;{ }^{1} \mathrm{H}$ NMR $\left(400 \mathrm{MHz}, d_{6}\right.$ DMSO): $\delta(\mathrm{ppm}) 8.83(\mathrm{~s}, 1 \mathrm{H}), 7.4(\mathrm{~d}, J=8.8 \mathrm{~Hz}, 1 \mathrm{H}), 7.28(\mathrm{br}, 1 \mathrm{H}), 7.14(\mathrm{~d}, J=2.8 \mathrm{~Hz}, 1 \mathrm{H})$, $6.87\left(\mathrm{dd}, J_{1}=8.8 \mathrm{~Hz}, J_{2}=2.4 \mathrm{~Hz}\right), 5.87$ (d, $\left.J=4 \mathrm{~Hz}, 1 \mathrm{H}\right), 5.50$ (br, 1H), 5.37 (br, 1H), 5.15 (br, 1H), 4.15-4.09 (m, 2H), 3.96-3.95 (m,1H), 3.81 (br, 1H), 3.77 (s, 3H), 3.68-3.65 (m, $1 \mathrm{H}) ;{ }^{13} \mathrm{C}$ NMR (100 MHz, $d_{6}$-DMSO): $\delta$ (ppm) 160.4, 155.7, 149.8, 149.7, 147.9, 137.2, $129.5,112.6,111.2,104.9,104.2,103.6,88.7,84.7,74.4,69.5,60.1,55.6 ;$ HRMS: m/z Calculated. for $\mathrm{C}_{18} \mathrm{H}_{18} \mathrm{~N}_{2} \mathrm{NaO}_{8}[\mathrm{M}+\mathrm{Na}]^{+}=413.0961$, found $=413.0968$. 
5-(5-methoxybenzofuran)-uridine triphosphate (2): To a solution of 5-(5methoxybenzofuran)-uridine (1) (77 $\mathrm{mg}, 0.197 \mathrm{mmol}, 1.0$ equiv) in trimethyl phosphate, freshly distilled $\mathrm{POCl}_{3}$ (46 $\mu \mathrm{L}, 0.49$ mmol, 2.5 equiv) was added in ice-cold condition. The solution was stirred for $24 \mathrm{~h}$ at $\sim 4{ }^{\circ} \mathrm{C}$. After $24 \mathrm{~h}$, it was observed that the starting material was not consumed completely. Bis(tributylammonium) pyrophosphate solution in DMF (0.5 M, $1.97 \mathrm{ml}, 0.99 \mathrm{mmol}, 5.0$ equiv) and tributylamine (0.52 ml, $2.17 \mathrm{mmol}, 11.0$ equiv) were simultaneously added to the reaction mixture in ice-cold condition. The reaction mixture was stirred for $30 \mathrm{~min}$ at $4{ }^{\circ} \mathrm{C}$ and quenched with $1 \mathrm{M}$ triethyl ammonium bicarbonate buffer (TEAB, pH 7.5, $15 \mathrm{ml})$ and washed with ethyl acetate $(2 \times 15 \mathrm{ml})$. The aqueous layer was evaporated to dryness and purified using an DEAE sephadex-A25 anion exchange column (10 mM-1M TEAB buffer, $\mathrm{pH}$ 7.5) followed by reverse phase flash chromatography (C18 RediSepRf, 0-50\% acetonitrile in $100 \mathrm{mM}$ triethylammonium acetate buffer, $\mathrm{pH} 7.2$, flow rate $6 \mathrm{ml} / \mathrm{min}, 55 \mathrm{~min}$ ). Evaporation of the appropriate fraction resulted into the desired triphosphate 2 as tetraethyl ammonium salt (31 mg, $15 \%$ ). ${ }^{1} \mathrm{H}$ NMR $\left(400 \mathrm{MHz}, \mathrm{D}_{2} \mathrm{O}\right): \delta$ (ppm) 7.82 (s, 1H), 7.39-7.38 (m, 1H), 6.93-6.83 (m, 3H), 5.79 (br, 1H), 4.41-4.34 (m, 5H), $3.79(\mathrm{~s}, 3 \mathrm{H}) ;{ }^{13} \mathrm{C}$ NMR $\left(100 \mathrm{MHz}, \mathrm{D}_{2} \mathrm{O}\right): \delta(\mathrm{ppm}) 161.5,155.0,150.4,150.4,148.5,136.4$, $129.3,112.9,111.8,106.1,105.2,103.9,89.6,83.1,73.5,69.8,65.7,55.8 ;{ }^{31} \mathrm{P}$ NMR spectrum was recorded after anion-exchange chromatography but before reverse-phase flash chromatography. ${ }^{31} \mathrm{P}$ NMR (162 MHz, $\left.\mathrm{D}_{2} \mathrm{O}\right):-6.46$ (br, $\left.\mathrm{P}_{\gamma}\right),-11.51\left(\mathrm{~d}, J=14.42 \mathrm{~Hz}, \mathrm{P}_{\alpha}\right)$, 22.32 (br, $\mathrm{P}_{\beta}$ ); HRMS: $\mathrm{m} / \mathrm{z}$ Calculated for $\mathrm{C}_{18} \mathrm{H}_{20} \mathrm{~N}_{2} \mathrm{O}_{17} \mathrm{P}_{3}[\mathrm{M}-\mathrm{H}]^{-}=628.9975$, found $=$ 628.9985 .

\section{Photophysical analysis of 5-methoxybenzofuran-modified uridine analogue 1 in different solvents.}

UV-absorption and steady-state fluorescence studies: UV-absorption spectrum of nucleoside $1(25 \mu \mathrm{M})$ was recorded on a Shimadzu UV-2600 spectrophotometer in quartz cuvette (Hellma, path length $1 \mathrm{~cm}$ ). Each UV sample contained 2.5\% DMSO. Steady-state fluorescence study of nucleoside $1(5 \mu \mathrm{M})$ in different solvent was performed in a micro fluorescence cuvette (Hellma, path length $1 \mathrm{~cm}$ ) on Fluoromax-4 spectrofluorometer. In this study, samples were excited at their lowest energy absorption maximum (Main manuscript Table 1). Each fluorescence sample contained 0.5\% DMSO. Anisotropy value $(r)$ of nucleoside 1 in different solvents was determined by analysing the data using software provided with the instrument. Each anisotropy value was an average of 10 successive 
measurements. All UV-absorption, steady-state fluorescence and anisotropy measurements were performed in triplicate.

Quantum yield determination: Quantum yield of nucleoside 1 in different solvents was determined relative to 2-aminopurine as the standard. Following equation was used to calculate the quantum yield. ${ }^{\mathrm{S} 3}$

$\Phi_{\mathrm{F}(\mathrm{x})}=\left(\mathrm{A}_{\mathrm{s}} / \mathrm{Ax}_{\mathrm{x}}\right)\left(\mathrm{F}_{\mathrm{x}} / \mathrm{F}_{\mathrm{s}}\right)\left(n_{\mathrm{x}} / n_{\mathrm{s}}\right)^{2} \Phi_{\mathrm{F}(\mathrm{s})}$

Where $\mathrm{s}$ is the standard, $\mathrm{x}$ is the modified nucleoside, $\mathrm{A}$ is the absorbance at excitation wavelength, $\mathrm{F}$ is the area under the emission curve, $n$ is the refractive index of the solvent, and $\Phi_{\mathrm{F}}$ is the quantum yield. Quantum yield of 2-aminopurine in water is 0.68 .
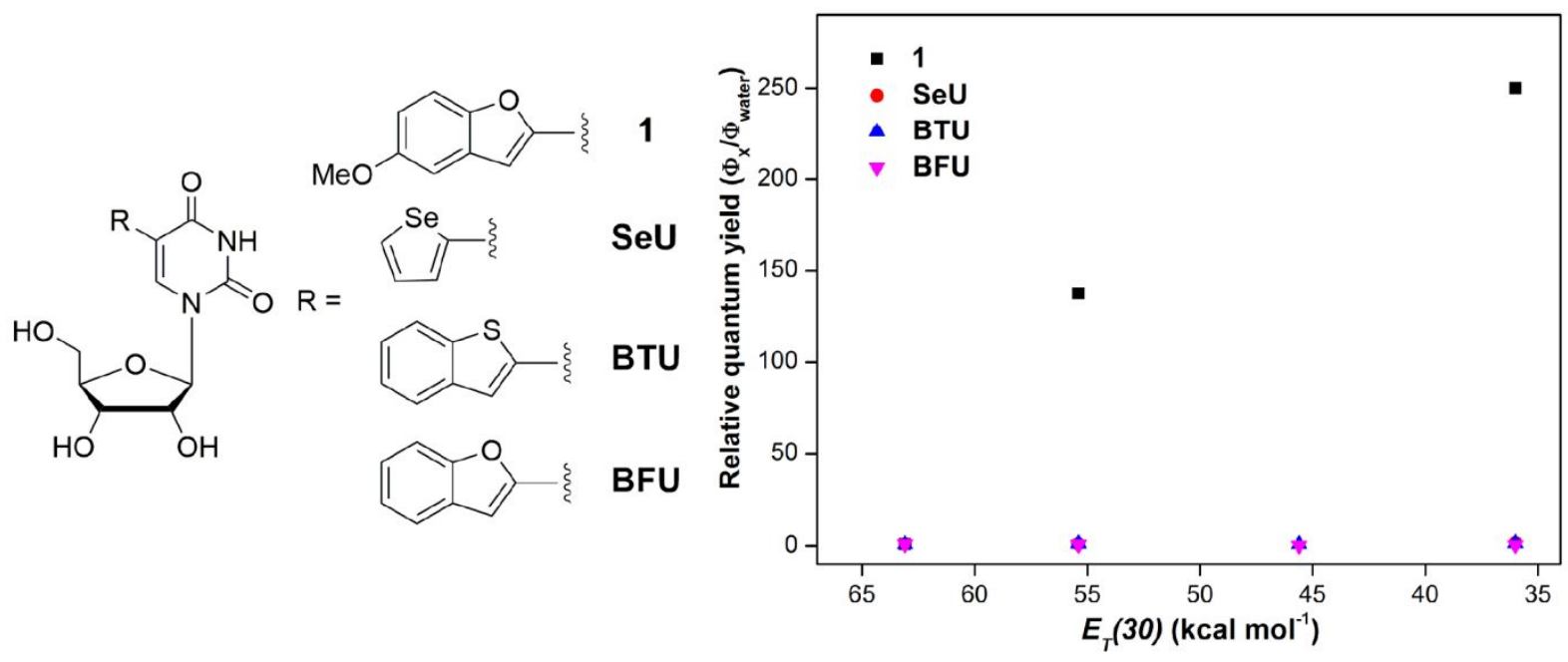

Figure S1. Relative quantum yield $\left(\left(\Phi_{\mathrm{x}} / \Phi_{\text {water }}\right), \mathrm{x}=\right.$ particular solvent $)$ versus $E_{T}(30)$ plot for nucleoside 1 and other heterocycle-conjugated nucleoside probes $\left(\mathrm{SeU}^{\mathrm{S} 4}, \mathrm{BTU}^{\mathrm{S} 5}\right.$ and $\left.\mathrm{BFU}^{\mathrm{S} 6}\right)$ in solvents with different polarity.

5. Transcription reaction with $\alpha_{-32}{ }^{32}$ ATP. Promoter-template duplexes were formed by annealing a 1:1 solution of DNA template T1-T5 $(5 \mu \mathrm{M})$ and RNA polymerase consensus 18-mer promoter DNA sequence in TE buffer $(10 \mathrm{mM}$ Tris-HCl, $1 \mathrm{mM}$ EDTA, $100 \mathrm{mM}$ $\mathrm{NaCl}, \mathrm{pH} \mathrm{7.8)}$ at $90{ }^{\circ} \mathrm{C}$ for $3 \mathrm{~min}$ and allowing it to attain room temperature. The solution was placed on an ice bath for $30 \mathrm{~min}$ and stored at $-40{ }^{\circ} \mathrm{C}$. Transcription was performed at 37 ${ }^{\circ} \mathrm{C}$ in $40 \mathrm{mM}$ Tris- $\mathrm{HCl}$ buffer (pH 7.8) using $250 \mathrm{nM}$ annealed promoter-template duplexes, $10 \mathrm{mM} \mathrm{NaCl}, 10 \mathrm{mM} \mathrm{MgCl} 2,10 \mathrm{mM}$ of dithiothreitol (DTT), $2 \mathrm{mM}$ spermidine, $1 \mathrm{U} / \mu \mathrm{L}$, RNase inhibitor (Riboblock), 1 mM GTP, CTP, UTP and or modified UTP 2, $20 \mu \mathrm{M}$ ATP, 5 $\mu \mathrm{Ci} \alpha-{ }^{32} \mathrm{P}$ ATP and $3 \mathrm{U} / \mu \mathrm{L}$ (total 60 units) T7 RNA polymerase in a total $20 \mu \mathrm{L}$ reaction volume. After $3.5 \mathrm{~h}$, the reaction was quenched using $20 \mu \mathrm{L}$ of loading buffer ( $7 \mathrm{M}$ urea in 10 
$\mathrm{mM}$ Tris-HCl, $100 \mathrm{mM}$ EDTA, $0.05 \%$ bromophenol blue, $\mathrm{pH} 8)$. The samples were heated at $75{ }^{\circ} \mathrm{C}$ for $3 \mathrm{~min}$ and then cooled on an ice bath. The samples $(4 \mu \mathrm{L})$ were loaded on a sequencing $18 \%$ denaturing polyacrylamide gel and were electrophoresed at a constant power $(11 \mathrm{~W})$ for nearly $4 \mathrm{~h}$. The bands corresponding to the radioactive products were imaged using an X-ray film. The relative transcription efficiency was calculated using GeneTools software from Syngene. The \% of incorporation of modified UTP 2 into RNA transcripts was determined considering the transcription efficiency in presence of all natural NTPs as $100 \%$. All reactions were performed in duplicate and the errors in yields were $\leq 4 \%$. See Figure S2.

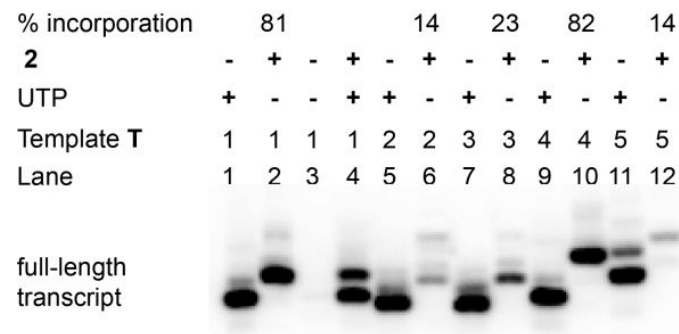

$\alpha-{ }^{32} \mathrm{P}$ ATP

Figure S2. Phosphor image of PAGE resolved transcription products obtained using DNA templates T1-T5 in the presence of UTP and or 2. \% Incorporation of 2 is calculated relative to control transcription reaction with UTP. See section 5 for details.

6. Large-scale transcription. Large-scale transcription reaction with a total volume of 250 $\mu \mathrm{L}$ was performed with the template $\mathbf{T 1}$. The transcription reaction was performed in the presence of $2 \mathrm{mM} \mathrm{GTP}$, ATP, CTP and modified UTP 2, $20 \mathrm{mM} \mathrm{MgCl}_{2}, 0.4 \mathrm{U} / \mu \mathrm{L}$ of RNase inhibitor (RiboLock), 800 units T7 RNA polymerase and $300 \mathrm{nM}$ promoter template duplex. The transcription reaction was performed at $37^{\circ} \mathrm{C}$ for $12 \mathrm{~h}$. The reaction volume was reduced to almost one third of the total volume using speed vac. $40 \mu \mathrm{L}$ loading buffer $(10 \mathrm{mM}$ Tris $\mathrm{HCl}, 7 \mathrm{M}$ urea, $100 \mathrm{mM}$ EDTA, $\mathrm{pH}$ 8.0) was added to the residual mixture and loaded onto to 
the $20 \%$ polyacrylamide gel and run at $25 \mathrm{~W}$ constant power for $6 \mathrm{~h}$. Gel was UV shadowed, the band corresponding to full-length transcript was cut and transferred to the Poly-Prep column (Bio-Rad). The gel pieces were crushed; the transcript was extracted with $0.5 \mathrm{M}$ ammonium acetate for $12 \mathrm{~h}$ and desalted using Sep-Pak classic C18 cartridges (Waters). Around 10-12 nmole of transcript $4\left(\varepsilon_{260}=91560 \mathrm{M}^{-1} \mathrm{~cm}^{-1}\right)$ was isolated from each reaction. The purity of the transcript was examined by HPLC and the transcript was characterized by MALDI TOF mass analysis (see Figure S3).
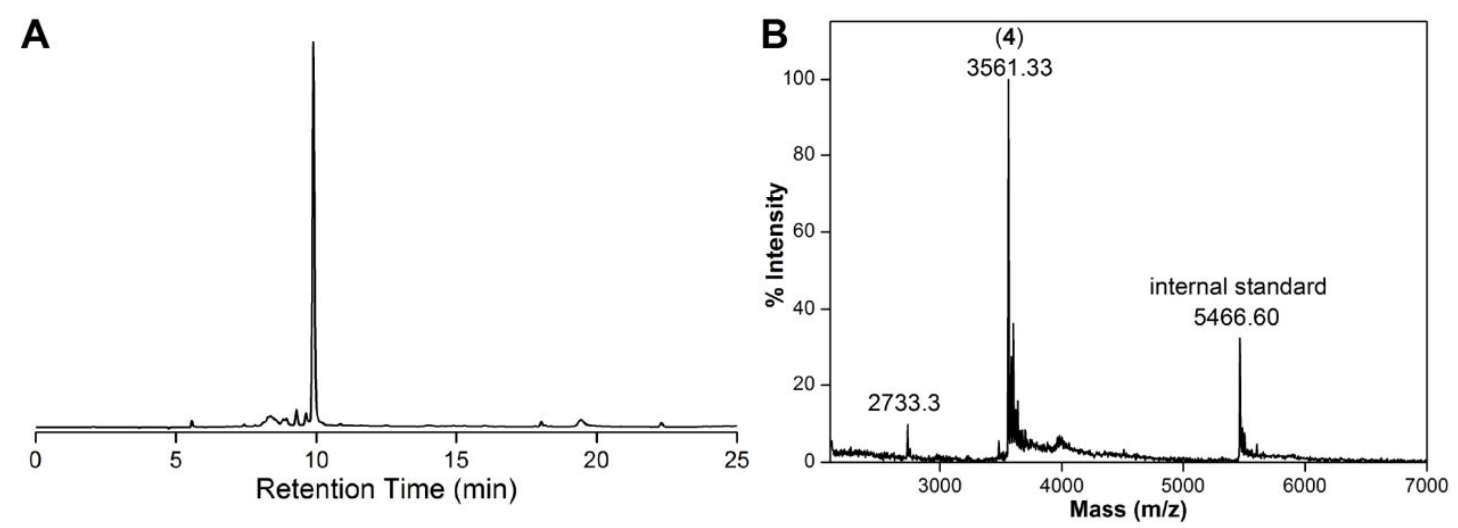

Figure S3. (A) HPLC chromatogram of PAGE purified transcript 4. Mobile Phase: $A=50 \mathrm{mM}$ triethylammonium acetate buffer $(\mathrm{pH} 7.5)$, mobile phase $\mathrm{B}$ : acetonitrile. Flow rate: $1 \mathrm{~mL} / \mathrm{min}$. Gradient: $0-50 \%$ B in $20 \mathrm{~min}$ and $50-100 \%$ B in $5 \mathrm{~min}$. (B) MALDI-TOF spectrum of transcript 4 calibrated relative to the +1 and +2 ions of an internal 18-mer DNA ON standard $(\mathrm{m} / \mathrm{z}$ for +1 and +2 ions are 5466.6 and 2733.3, respectively). $\mathrm{m} / \mathrm{z}$ calculated for 4: 3561.1 [M]; found: 3561.3 .

7. MALDI-TOF mass analysis of transcript 4: A mixture of $2 \mu \mathrm{L}$ of the transcript $4(\sim 200$ $\mu \mathrm{M}), 4 \mu \mathrm{L}$ of a 9:1 solution of 3-hydroxypicolinic acid and ammonium citrate buffer (100 $\mathrm{mM}, \mathrm{pH} 9)$ and $2 \mu \mathrm{L}$ of an internal DNA standard $(100 \mu \mathrm{M})$ was desalted using an ionexchange resin (Dowex 50W-X8, 100-200 mesh, ammonium form). The sample was then spotted on a MALDI plate, air dried and subjected to mass analysis. The spectrum was calibrated relative to the internal DNA standard (see Figure S3).

8. Enzymatic digestion of transcript 4. Transcript 4 ( $2.5 \mathrm{nmole})$ was incubated with snake venom phosphodiesterase I $(0.01 \mathrm{U})$, calf intestinal alkaline phosphatase $(1 \mathrm{U} / \mu \mathrm{L})$ and RNase A $(0.25 \mu \mathrm{g}), 50 \mathrm{mM}$ Tris- $\mathrm{HCl}$ buffer $(\mathrm{pH} 8.5,40 \mathrm{mM} \mathrm{MgCl} 2,0.1 \mathrm{mM}$ EDTA) in a total volume of $100 \mu \mathrm{L}$ for $12 \mathrm{~h}$ at $37^{\circ} \mathrm{C}$. Afterwards, RNase T1 $(0.2 \mathrm{U} / \mu \mathrm{L})$ was added and the sample was incubated for additional $4 \mathrm{~h}$ at $37^{\circ} \mathrm{C}$. The resulting mixture obtained from the digestion was analyzed by RP-HPLC using Phenomenex-Luna C18 column $(250 \times 4.6 \mathrm{~mm}, 5$ micron) at 260 and $330 \mathrm{~nm}$. Mobile phase A: 50mM TEAA buffer (pH 7.5), mobile phase B: 
acetonitrile. Flow rate: $1 \mathrm{ml} / \mathrm{min}$. Gradient: $0-10 \% \mathrm{~B}$ in $20 \mathrm{~min}, 10-100 \% \mathrm{~B}$ in $10 \mathrm{~min}$ (Figure S4). Further to characterize the ribonucleosides in digest, the fraction corresponding to the individual ribonucleoside was collected and analyzed by mass spectroscopy (Table S1).

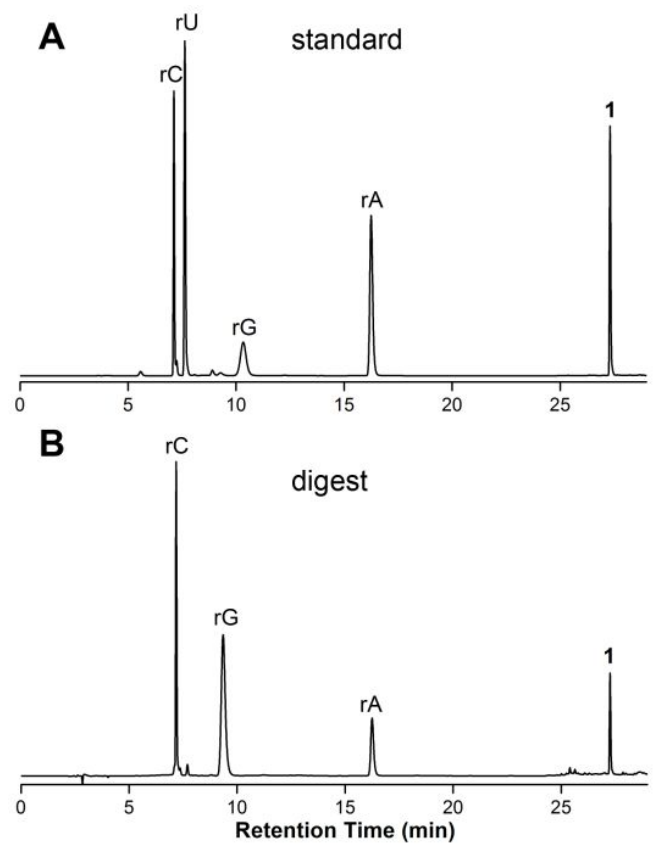

Figure S4. HPLC chromatogram of (A) Natural ribonucleosides $\mathrm{rC}, \mathrm{rU}, \mathrm{rG}, \mathrm{rA}$ and nucleoside $\mathbf{1}$ mix. and (B) ribonucleosides obtained from enzymatic digestion of transcript 4. See section 8 for more details.

Table S1. MALDI-TOF mass analysis of HPLC fractions of transcript 4 digest

\begin{tabular}{ccc}
\hline HPLC fraction of the digest & Calculated mass & Observed mass \\
\hline $\mathrm{rC}$ & $\mathrm{C}_{9} \mathrm{H}_{13} \mathrm{KN}_{3} \mathrm{O}_{5}: 282.0[\mathrm{M}+\mathrm{K}]^{+}$ & 282.0 \\
$\mathrm{rG}$ & $\mathrm{C}_{10} \mathrm{H}_{13} \mathrm{~N}_{5} \mathrm{NaO}_{5}: 306.1[\mathrm{M}+\mathrm{Na}]^{+}$ & 306.0 \\
$\mathrm{rA}$ & $\mathrm{C}_{10} \mathrm{H}_{13} \mathrm{~N}_{5} \mathrm{NaO}_{4}: 290.1[\mathrm{M}+\mathrm{Na}]^{+}$ & 290.0 \\
$\mathbf{1}$ & $\mathrm{C}_{18} \mathrm{H}_{18} \mathrm{KN}_{2} \mathrm{O}_{8}: 429.1[\mathrm{M}+\mathrm{K}]^{+}$ & 429.0 \\
\hline
\end{tabular}

\section{Steady-state fluorescence studies of transcript 4 and its duplexes in the presence and} absence of metal ions. Transcript $4(1 \mu \mathrm{M})$ and 1:1 mixtures of transcript $4(1 \mu \mathrm{M})$ and its prefect complementary and mismatched DNA or RNA ONs were heated at $90{ }^{\circ} \mathrm{C}$ for $3 \mathrm{~min}$ in sodium cacodylate buffer $(10 \mathrm{mM}, \mathrm{pH} 7.0)$ containing $500 \mathrm{mM} \mathrm{NaNO}_{3}$ either in presence or absences of 1 equivalent $(1 \mu \mathrm{M})$ of respective metal ions. Samples were allowed to come to 
room temperature over a period of $2 \mathrm{~h}$ and kept at $4{ }^{\circ} \mathrm{C}$ for $1 \mathrm{~h}$. Samples were excited at 340 $\mathrm{nm}$ with excitation and emission slit width $7 \mathrm{~nm}$ and $8 \mathrm{~nm}$, respectively.

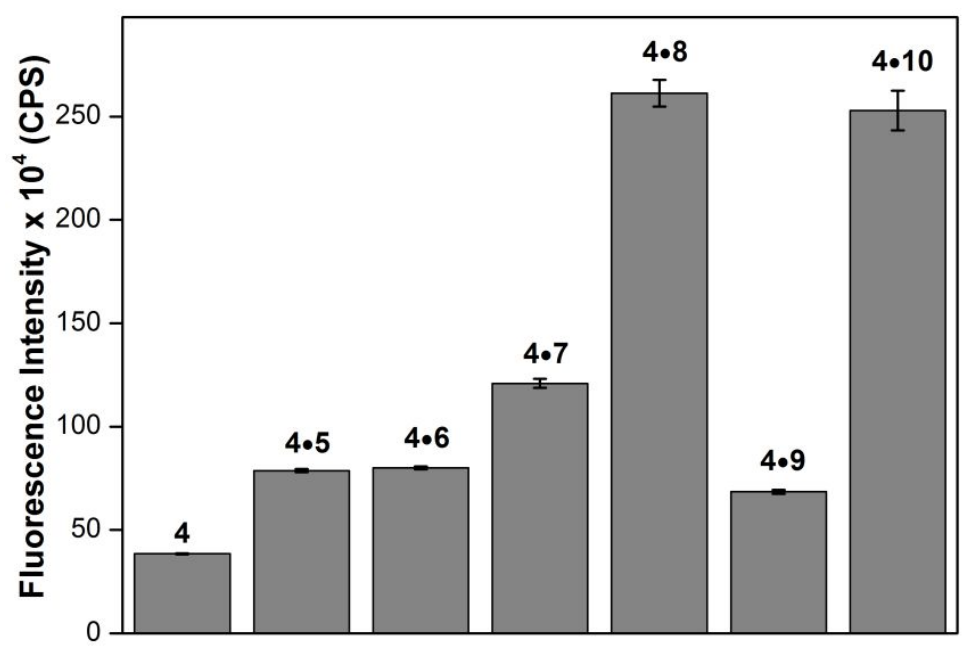

Figure S5. Fluorescence intensity of transcript 4 and its duplexes $(1 \mu \mathrm{M})$ with perfect complementary and mismatched DNA and RNA ONs at respective emission maximum in $10 \mathrm{mM}$ sodium cacodylate buffer pH 7.0 containing $500 \mathrm{mM} \mathrm{NaNO}$. Samples were excited at $340 \mathrm{~nm}$ with excitation and emission slit width of $7 \mathrm{~nm}$ and $8 \mathrm{~nm}$, respectively.

10. Circular dichroism (CD) studies. ON duplexes $(6 \mu \mathrm{M})$ were formed in sodium cacodylate buffer $(10 \mathrm{mM}, \mathrm{pH} 7.0)$ containing $500 \mathrm{mM} \mathrm{NaNO}_{3}$ by annealing as mentioned above. CD spectra were recorded from 200 to $350 \mathrm{~nm}$ in a quartz cuvette (Starna Scientific, path length $5 \mathrm{~mm}$ ) on a J-815 CD spectropolarimeter (Jasco, USA) using $1 \mathrm{~nm}$ bandwidth at $20{ }^{\circ} \mathrm{C}$. Each CD profile is an average of five scans collected at a scan speed of $100 \mathrm{~nm} \mathrm{~min}{ }^{-1}$. $\mathrm{CD}$ measurements were performed in duplicate and all spectra were corrected using an appropriate blank solution in the absence of ONs. 


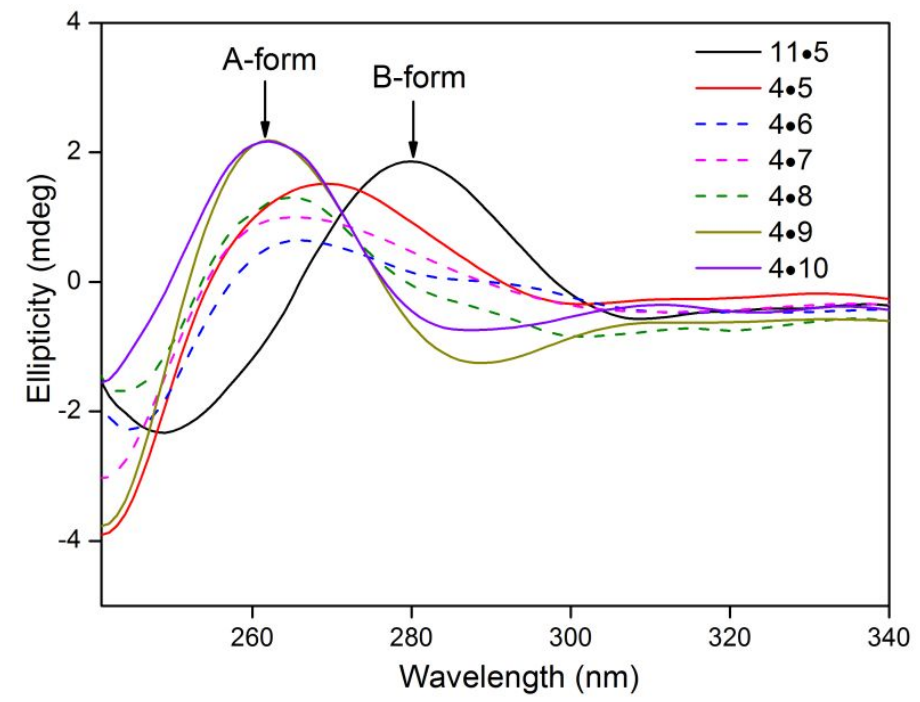

Figure S6. CD spectra $(6 \mu \mathrm{M})$ of control DNA-DNA duplex (11.5), modified DNA-RNA duplexes $(4 \cdot 5,4 \cdot 6,4 \cdot 7$ and $4 \cdot 8)$ and RNA-RNA duplexes $(4 \cdot 9$ and $\mathbf{4 \cdot 1 0})$ in $10 \mathrm{mM}$ sodium cacodylate buffer (pH 7.0) containing $500 \mathrm{mM} \mathrm{NaNO}$. DNA ON 11 5' d(GCGCCGTGCA) 3' was used for control DNA-DNA duplex formation.

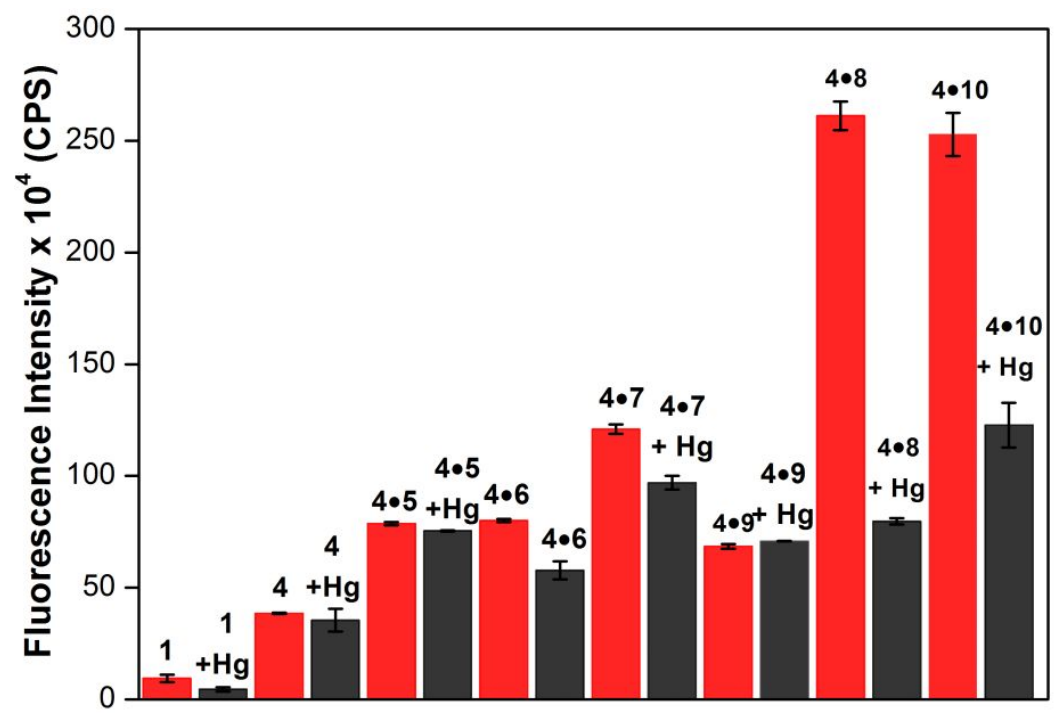

Figure S7. Fluorescence intensity of free nucleoside 1, transcript 4 and its duplexes $(1 \mu \mathrm{M})$ with perfect complementary and mismatched DNA and RNA ONs at respective emission maximum in the presence and absence of $1 \mu \mathrm{M} \mathrm{Hg}^{2+}$ ion. Samples were excited at $340 \mathrm{~nm}$ in $10 \mathrm{mM}$ sodium cacodylate buffer $\mathrm{pH} 7.0$ containing $500 \mathrm{mM} \mathrm{NaNO}_{3}$ with excitation and emission slit width of $7 \mathrm{~nm}$ and $8 \mathrm{~nm}$, respectively. 

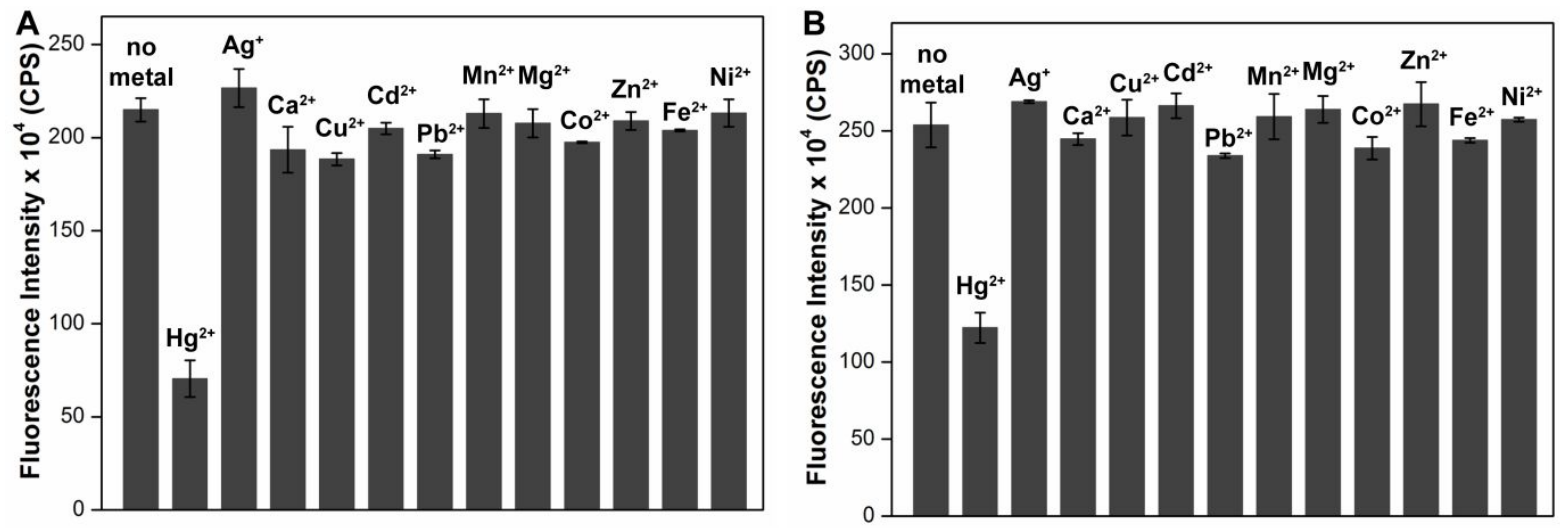

Figure S8. Fluorescence intensity of duplexes $(1 \mu \mathrm{M})(\mathbf{A}) \mathbf{4 \bullet 8}$ containing dT-1 mismatch and (B) 4.10 containing U-1 mismatch at $440 \mathrm{~nm}$ in the absence and presence of different metal ions $(1 \mu \mathrm{M}, 1$ equiv) in $10 \mathrm{mM}$ sodium cacodylate buffer $\mathrm{pH} 7.0$ containing $500 \mathrm{mM} \mathrm{NaNO}_{3}$. Samples were excited at $340 \mathrm{~nm}$ with excitation and emission slit width of $7 \mathrm{~nm}$ and $8 \mathrm{~nm}$, respectively.

11. Fluorescence binding assay. Duplexes $4 \cdot 8$ and $4 \cdot 10(10 \mu \mathrm{M})$ containing dT and $\mathrm{U}$ mispair were prepared in $10 \mathrm{mM}$ sodium cacodylate buffer, $\mathrm{pH} 7.0$ with $500 \mathrm{mM} \mathrm{NaNO} \mathrm{Na}_{3}$ above. From this stock, a series of duplex samples $(\mathbf{4 \cdot 8}$ or $\mathbf{4 \cdot 1 0}, 0.18 \mu \mathrm{M})$ containing increasing concentration of the $\mathrm{Hg}^{2+}$ ions (10 to $600 \mathrm{nM}$ ) was prepared and incubated for $1 \mathrm{~h}$ before fluorescence analysis. Samples were excited at $340 \mathrm{~nm}$ with an excitation and emission slit width of $10 \mathrm{~nm}$ and $12 \mathrm{~nm}$, respectively. The measurements were performed in triplicate at $20{ }^{\circ} \mathrm{C}$. The spectrum corresponding to a blank without any ON duplex but containing the respective $\mathrm{Hg}^{2+}$ ion concentration was subtracted from each spectrum. From the dose-dependent quenching curves, the apparent dissociation constant $\left(K_{d}\right)$ for the binding of $\mathrm{Hg}^{2+}$ to respective duplexes was determined by fitting normalized fluorescence intensity $\left(F_{N}\right)$ versus $\log$ of ligand concentration plot using Hill equation (Origin 8.5). ${ }^{\mathrm{S} 7}$

$F_{N}=\frac{F_{i}-F_{s}}{F_{0}-F_{s}}$

$F_{i}$ is the fluorescence intensity at each ligand concentration. $F_{0}$ and $F_{s}$ are the fluorescence intensity in the absence of ligand (L) and at saturation point, respectively. $n$ is the Hill coefficient or degree of cooperativity associated with the binding. The degree of cooperativity for DNA-RNA duplex $\mathbf{4 \cdot 8}$ and RNA-RNA duplex $\mathbf{4 \cdot 1 0}$ was found to be 1.7 and 3.4 , respectively.

$F_{N}=F_{0}+\left(F_{s}-F_{0}\right)\left(\frac{[L]^{n}}{\left[K_{d}\right]^{n}+[L]^{n}}\right)$ 

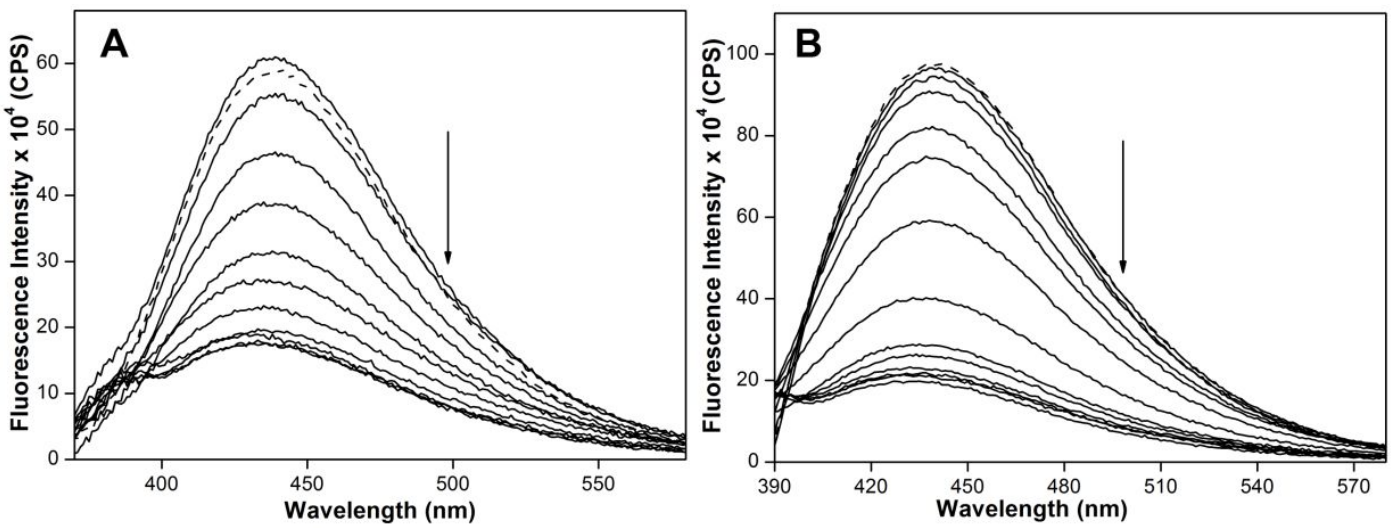

Figure S9. Emission spectra of fluorescently labeled duplexes (A) $4 \cdot 8$ and (B) $4 \cdot 10(0.18 \mu \mathrm{M})$ containing increasing concentration of $\mathrm{Hg}^{2+}$ ions in sodium cacodylate buffer $(10 \mathrm{mM}, \mathrm{pH} 7.0)$ containing $500 \mathrm{mM} \mathrm{NaNO}$. Samples were excited at $340 \mathrm{~nm}$ with excitation and emission slit width of $10 \mathrm{~nm}$ and $12 \mathrm{~nm}$, respectively.

12. Thermal melting analysis of $\mathrm{ON}$ duplexes. ON duplexes $(5 \mu \mathrm{M})$ were formed in sodium cacodylate buffer $(10 \mathrm{mM}, \mathrm{pH} 7.0)$ containing $500 \mathrm{mM} \mathrm{NaNO}_{3}$ as mentioned earlier, either in presence or absence of 1 equivalent $\mathrm{Hg}^{2+}$ ions $(5 \mu \mathrm{M})$. Thermal melting analysis was performed using Cary 300 Bio UV-Vis spectrophotometer. Temperature was increased from $18{ }^{\circ} \mathrm{C}$ to $90{ }^{\circ} \mathrm{C}$ at $1{ }^{\circ} \mathrm{C} / \mathrm{min}$ and the absorbance was measured every $1^{\circ} \mathrm{C}$ interval at $260 \mathrm{~nm}$. 

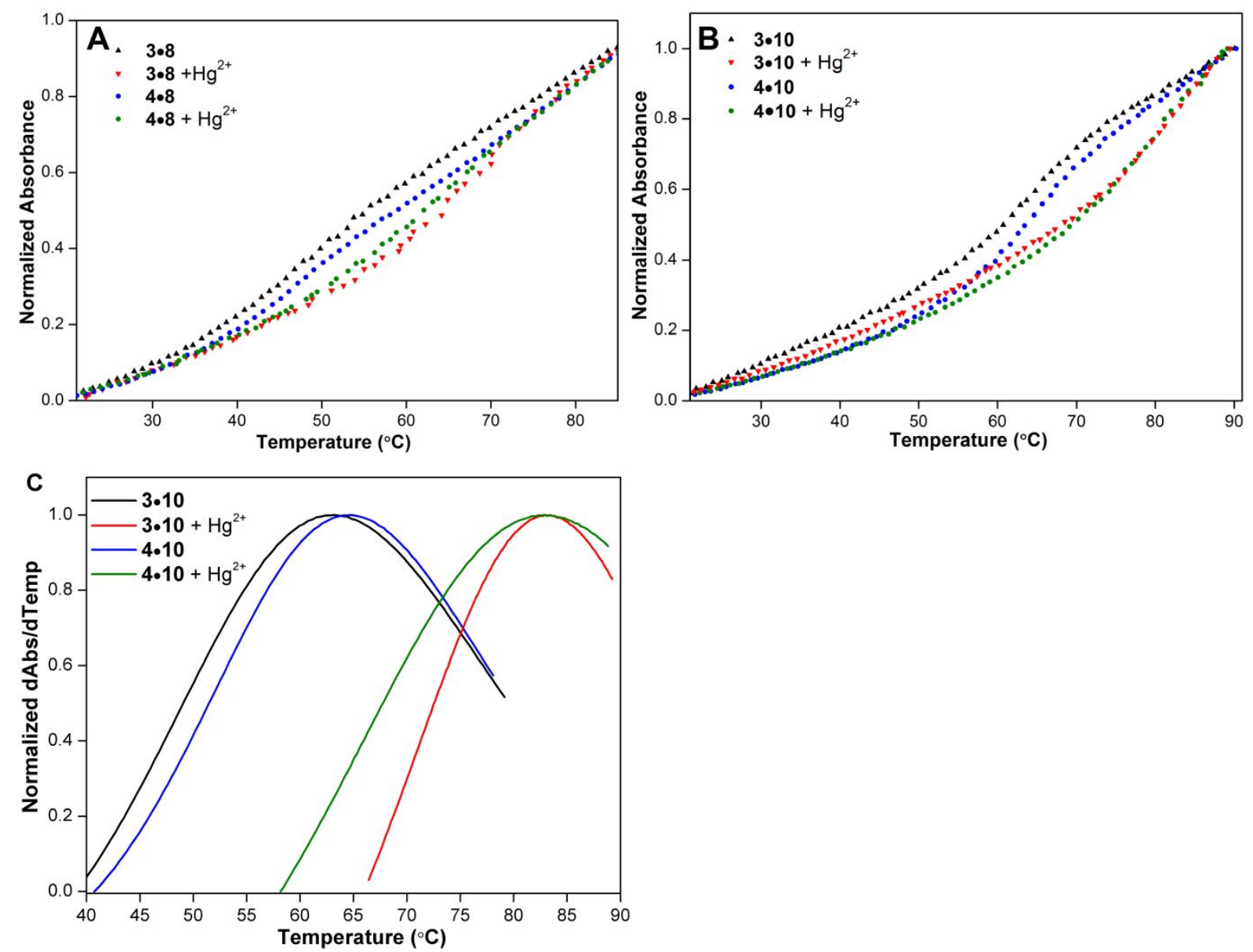

Figure S10. Representative UV-thermal melting profile of duplexes $(5 \mu \mathrm{M})(\mathbf{A}) \mathbf{3} \cdot \mathbf{8}, \mathbf{4} \cdot \mathbf{8}$ with dT-U or dT-1 mismatch and (B) 3•10, 4•10 with U-U or U-1 mismatch in the presence or absence of $\mathrm{Hg}^{2+}$ ions $(5 \mu \mathrm{M})$. (C) Representative first-derivative thermal melting curves of duplexes $\mathbf{3} \cdot \mathbf{1 0}$ (control) and $4 \cdot 10$ (modified) in the presence and absence of $\mathrm{Hg}^{2+}$ ions.

Table S2. $T_{m}$ values of control and modified duplexes.

\begin{tabular}{cccc}
\hline & ON duplexes & $\begin{array}{c}T_{m}\left({ }^{\circ} \mathrm{C}\right) \\
\text { in absence of } \mathrm{Hg}^{\mathrm{II}}\end{array}$ & $\begin{array}{c}T_{m}\left({ }^{\circ} \mathrm{C}\right) \\
\text { in presence of } \\
1 \text { equivalent } \mathrm{Hg}^{\mathrm{II}}\end{array}$ \\
\hline \multirow{6}{*}{ control } & $\mathbf{3 \bullet 5}$ & $59.7 \pm 0.9$ & $61.0 \pm 0.4$ \\
& $\mathbf{3 \bullet 6}$ & $53.7 \pm 0.4$ & $56.4 \pm 0.4$ \\
& $\mathbf{3 \bullet 7}$ & $44.9 \pm 0.9$ & $49.6 \pm 0.4$ \\
& $\mathbf{3 \bullet 8}$ & $46.1 \pm 0.8$ & $63.7 \pm 0.6$ \\
& $\mathbf{3 \bullet 9}$ & $77.8 \pm 0.4$ & $80.3 \pm 0.9$ \\
modified & $\mathbf{3 \bullet 1 0}$ & $61.5 \pm 0.5$ & $82.6 \pm 0.5$ \\
\hline & $\mathbf{4 \bullet 5}$ & $57.5 \pm 0.1$ & $57.7 \pm 0.8$ \\
& $\mathbf{4 \cdot 6}$ & $52.7 \pm 0.8$ & $54.7 \pm 0.5$ \\
& $\mathbf{4 \cdot 7}$ & $44.9 \pm 0.6$ & $45.8 \pm 0.3$ \\
& $\mathbf{4 \bullet 8}$ & $44.0 \pm 0.8$ & $60.7 \pm 0.9$ \\
& $\mathbf{4 \bullet 9}$ & $74.8 \pm 0.6$ & $73.5 \pm 0.5$ \\
& $\mathbf{4} 10$ & $63.3 \pm 0.2$ & $80.9 \pm 0.2$ \\
\hline
\end{tabular}


13. ${ }^{1} \mathrm{H}$ NMR analysis of $\mathrm{ON}$ duplexes. Duplex $4 \cdot 8(50 \mu \mathrm{M})$ with dT-1 mismatch and duplex 4•10 $(50 \mu \mathrm{M})$ with U-1 mismatch were formed in sodium cacodylate buffer (10 mM, pH 7.0) containing $500 \mathrm{mM} \mathrm{NaNO} 3$ similarly like steady-state fluorescence sample. After recording the ${ }^{1} \mathrm{H}$ NMR of the duplexes without $\mathrm{Hg}^{2+}$ ions, the concentration of $\mathrm{Hg}^{2+}$ in the sample was increased gradually by adding higher concentrations $(2.5 \mathrm{mM})$ of $\mathrm{Hg}^{2+}$ ions such that the final concentration of the metal salt was $25 \mu \mathrm{M}$ ( 0.5 equiv) and $50 \mu \mathrm{M}$ (1 equiv). After addition of $\mathrm{Hg}^{2+}$, samples were annealed as mentioned above.

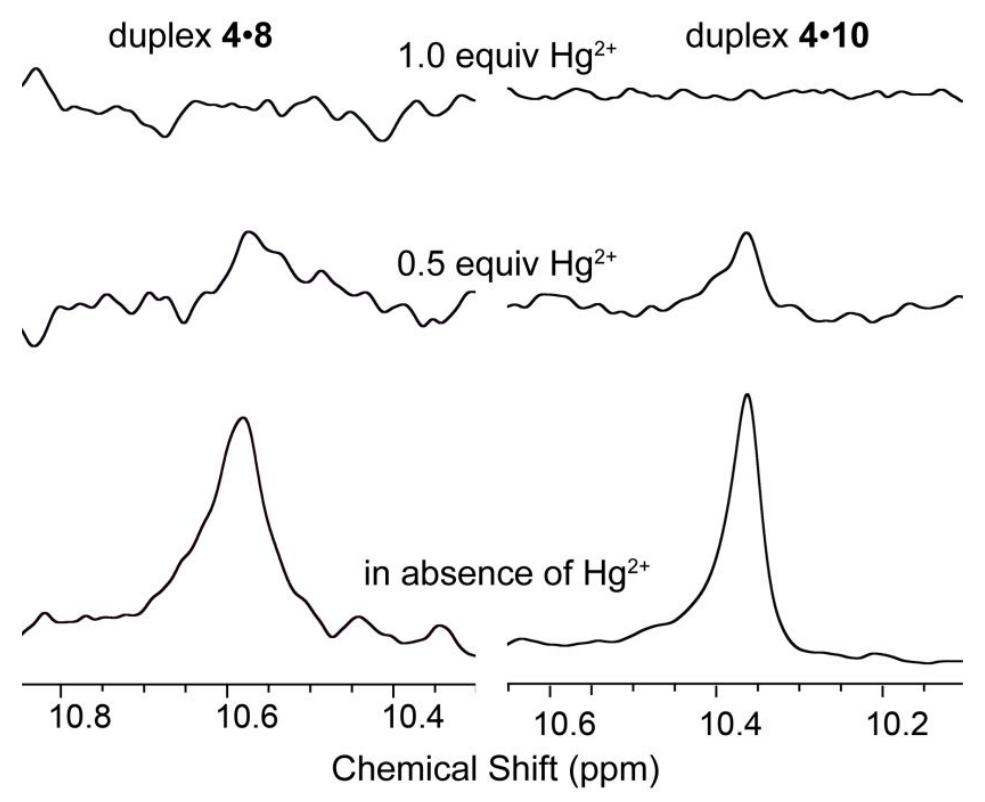

Figure S11. Partial ${ }^{1} \mathrm{H}$ NMR spectra of duplexes $\mathbf{4 \bullet 8}$ with dT-1 mismatch $(50 \mu \mathrm{M})$ and $\mathbf{4} \cdot \mathbf{1 0}$ with U-1 mismatch in the absence and presence of 0.5 equivalent $(25 \mu \mathrm{M})$ and 1.0 equivalent $(50 \mu \mathrm{M}) \mathrm{Hg}^{2+}$ ions. Spectra were recorded at $20^{\circ} \mathrm{C}$ in sodium cacodylate buffer $(10 \mathrm{mM}, \mathrm{pH} 7.0)$ containing 500 $\mathrm{mM} \mathrm{NaNO}$. Imino proton signals corresponding to mispair is shown here, which disappears upon metal ion coordination. ${ }^{\mathrm{s} 8}$ 


\section{NMR Spectra}

${ }^{1} \mathrm{H}$ NMR of $1 \mathbf{b}\left(400 \mathrm{MHz}, \mathrm{CDCl}_{3}\right.$ containing $0.03 \%$ (v/v) TMS)

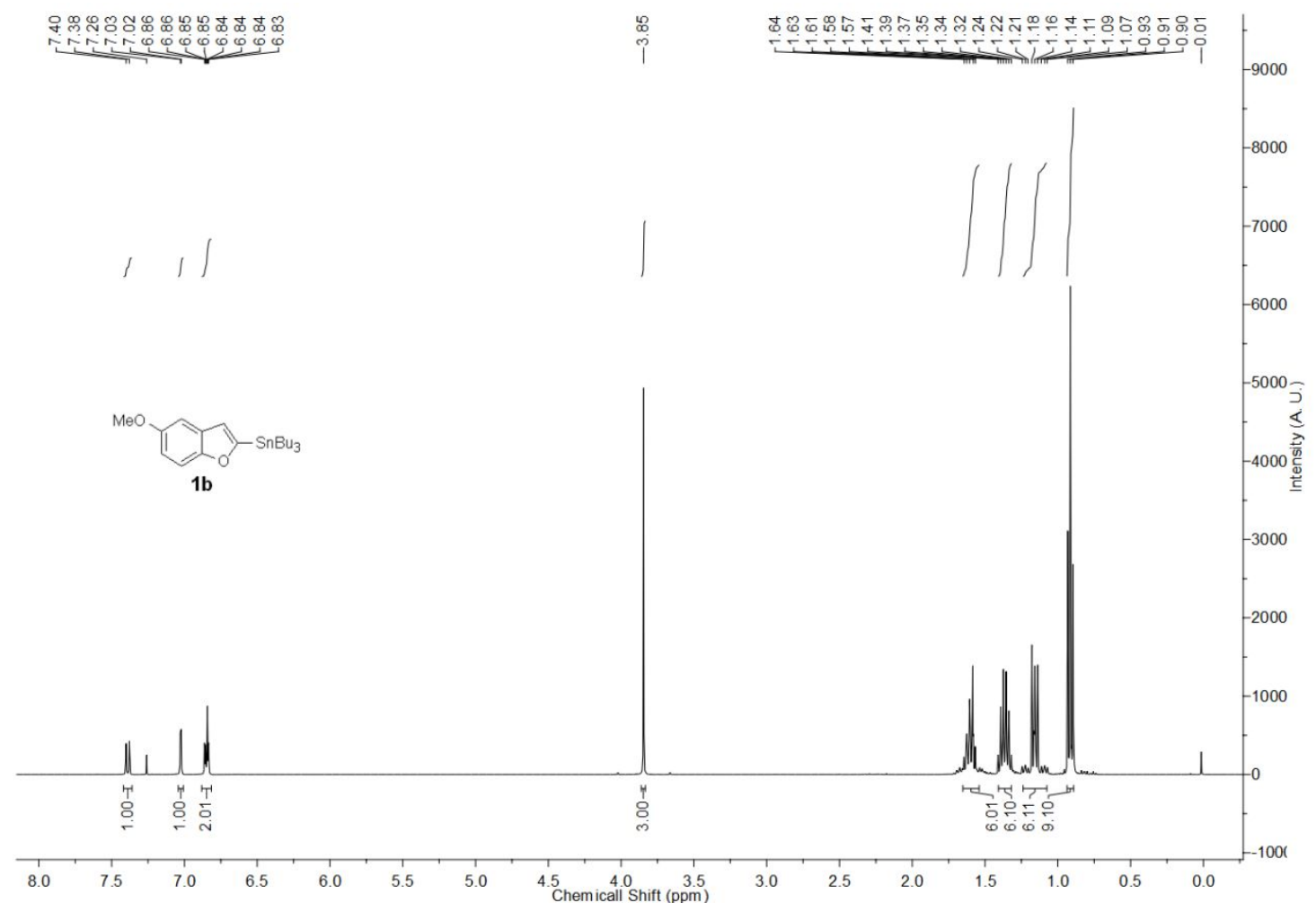

${ }^{13} \mathrm{C} \mathrm{NMR}$ of $\mathbf{1 b}\left(100 \mathrm{MHz}, \mathrm{CDCl}_{3}\right)$
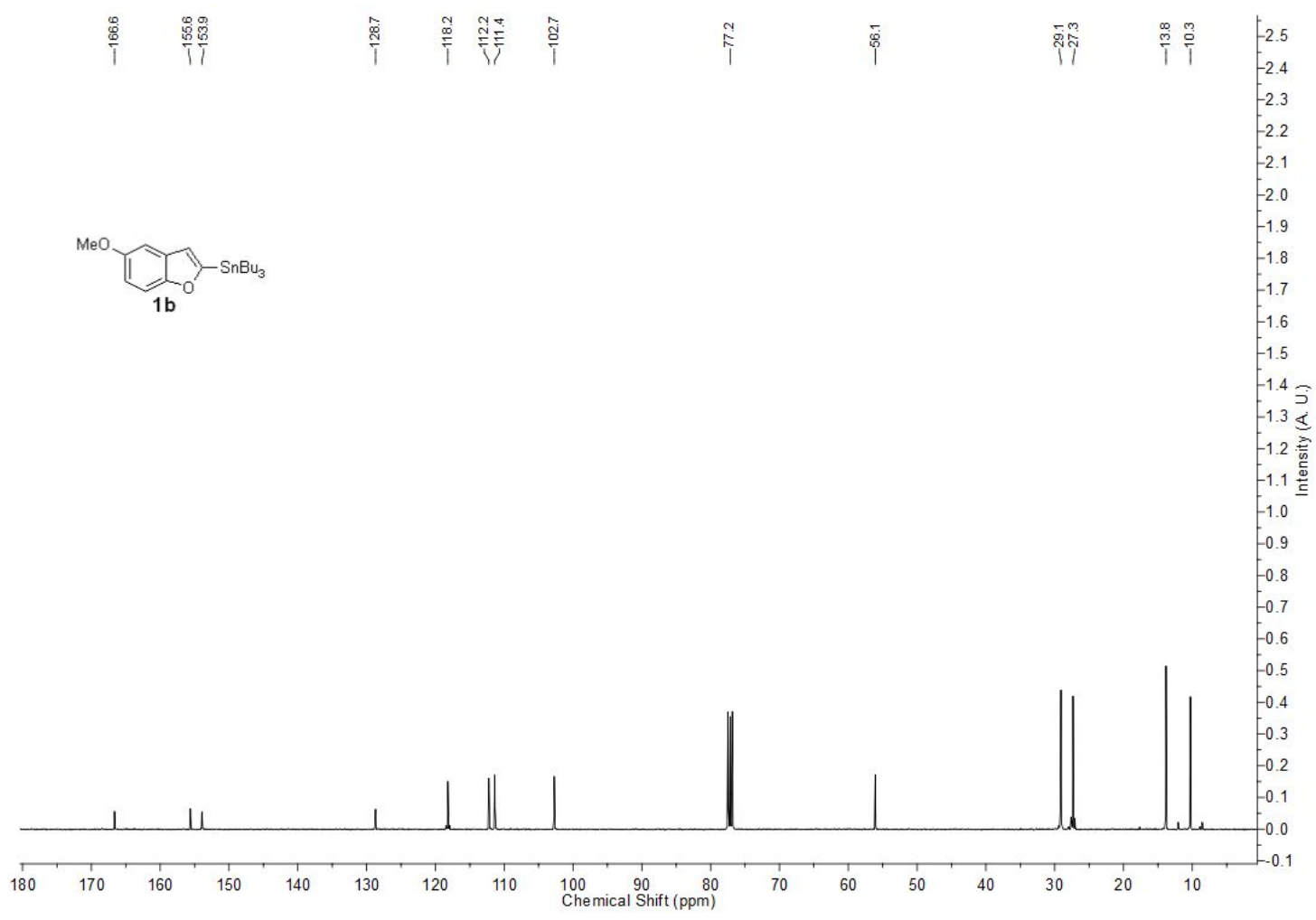
${ }^{1} \mathrm{H}$ NMR of 1 (400 MHz, $d_{6}$-DMSO)

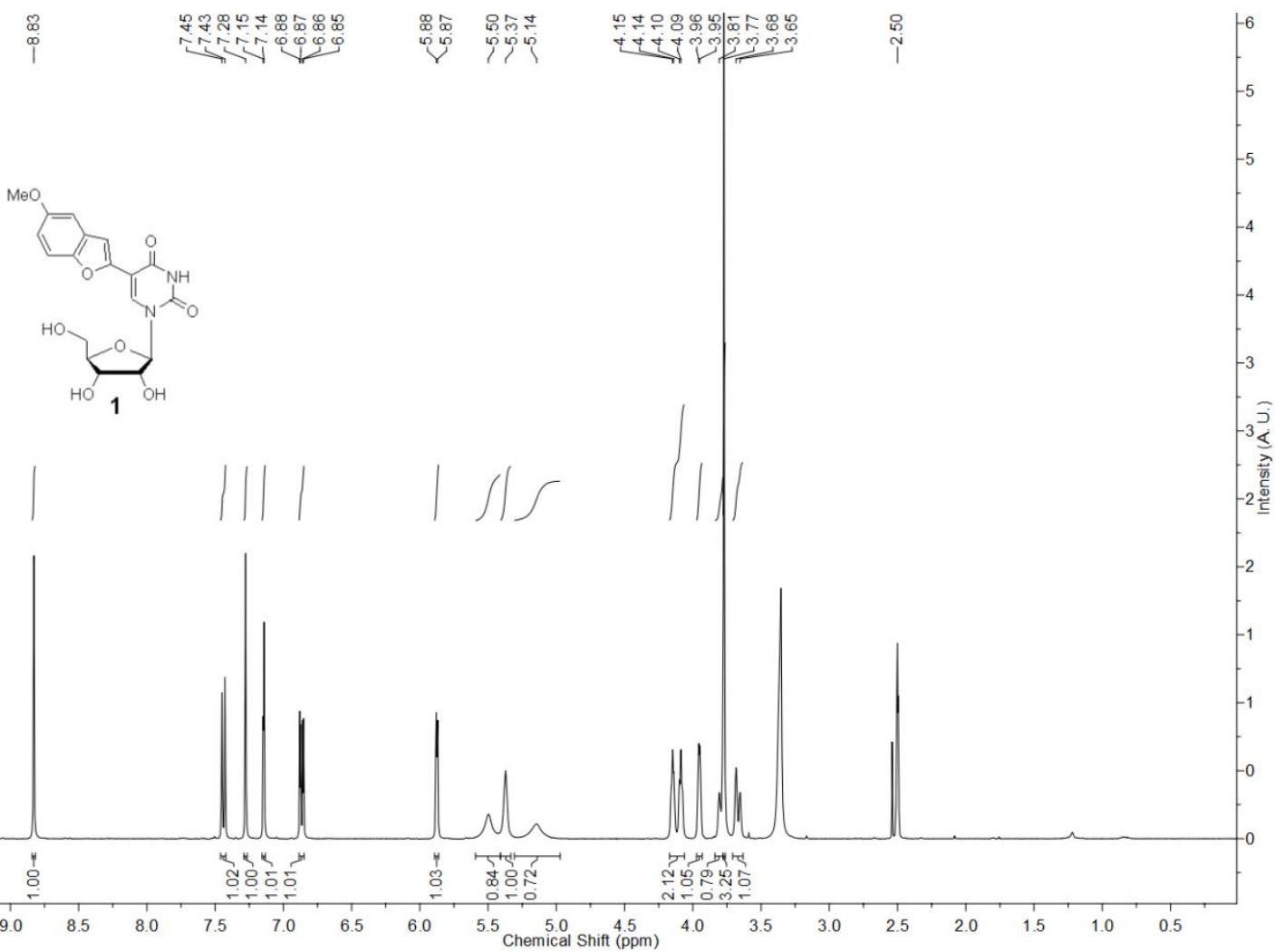

${ }^{13} \mathrm{C}$ NMR of $1\left(100 \mathrm{MHz}, d_{6}\right.$-DMSO)

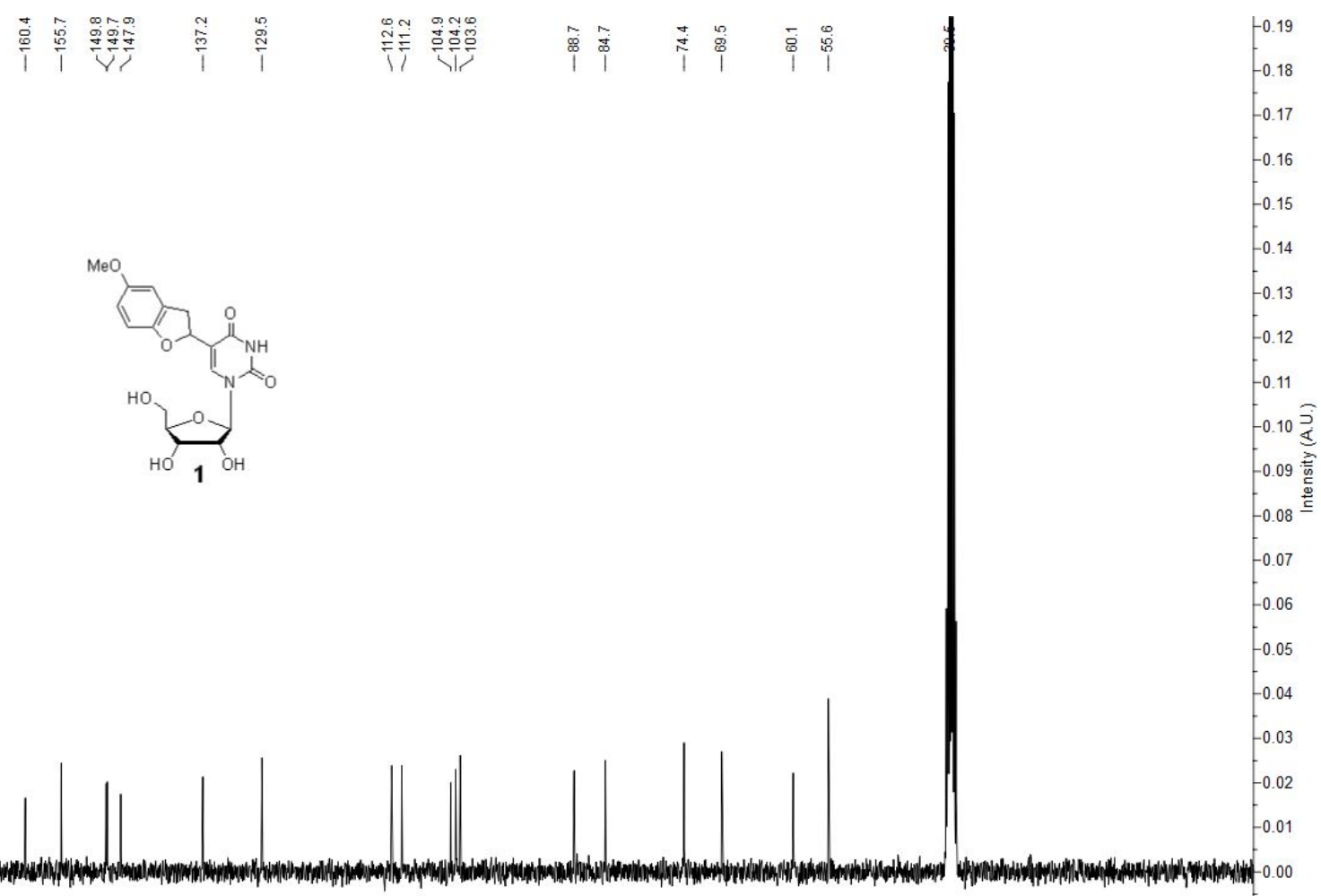

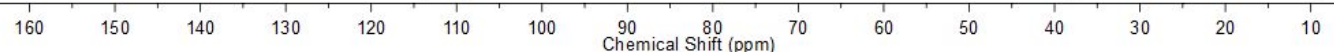


${ }^{1} \mathrm{H}$ NMR of $2\left(400 \mathrm{MHz}, \mathrm{D}_{2} \mathrm{O}\right)$, Trace amount of triethylammonium acetate buffer is present.

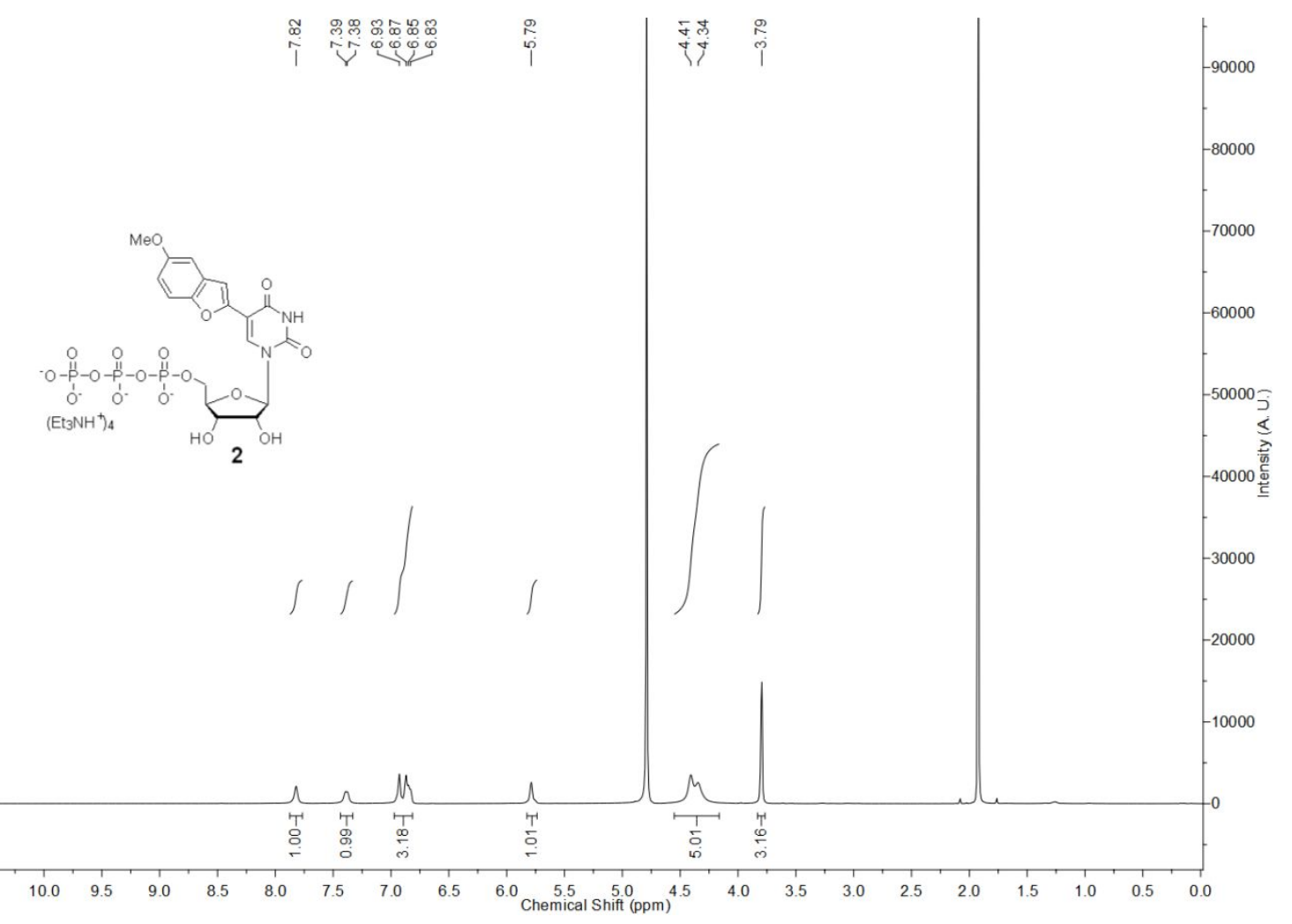

${ }^{13} \mathrm{C}$ NMR of $2\left(100 \mathrm{MHz}, \mathrm{D}_{2} \mathrm{O}\right)$, Trace amount of triethylammonium acetate buffer is present.

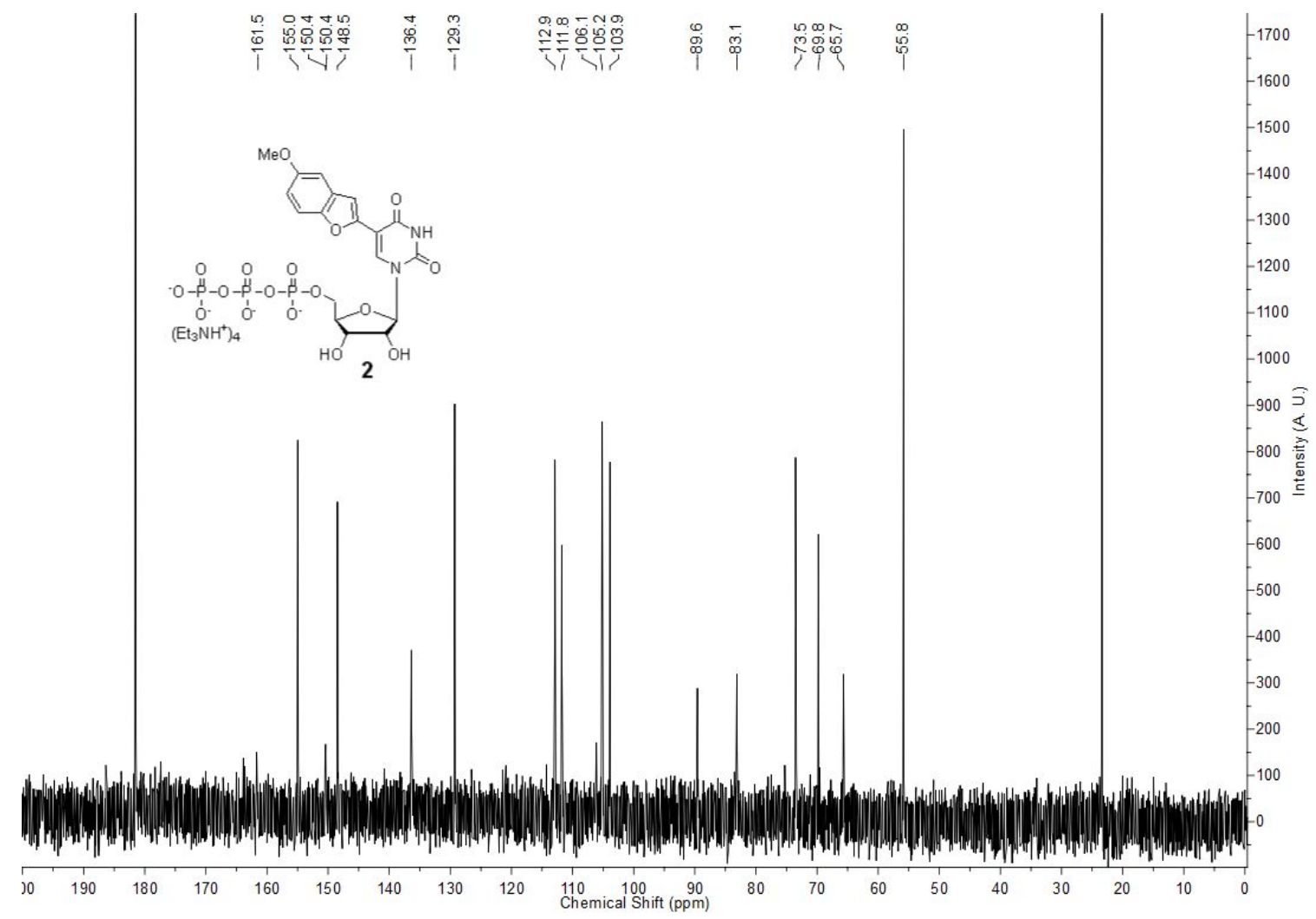




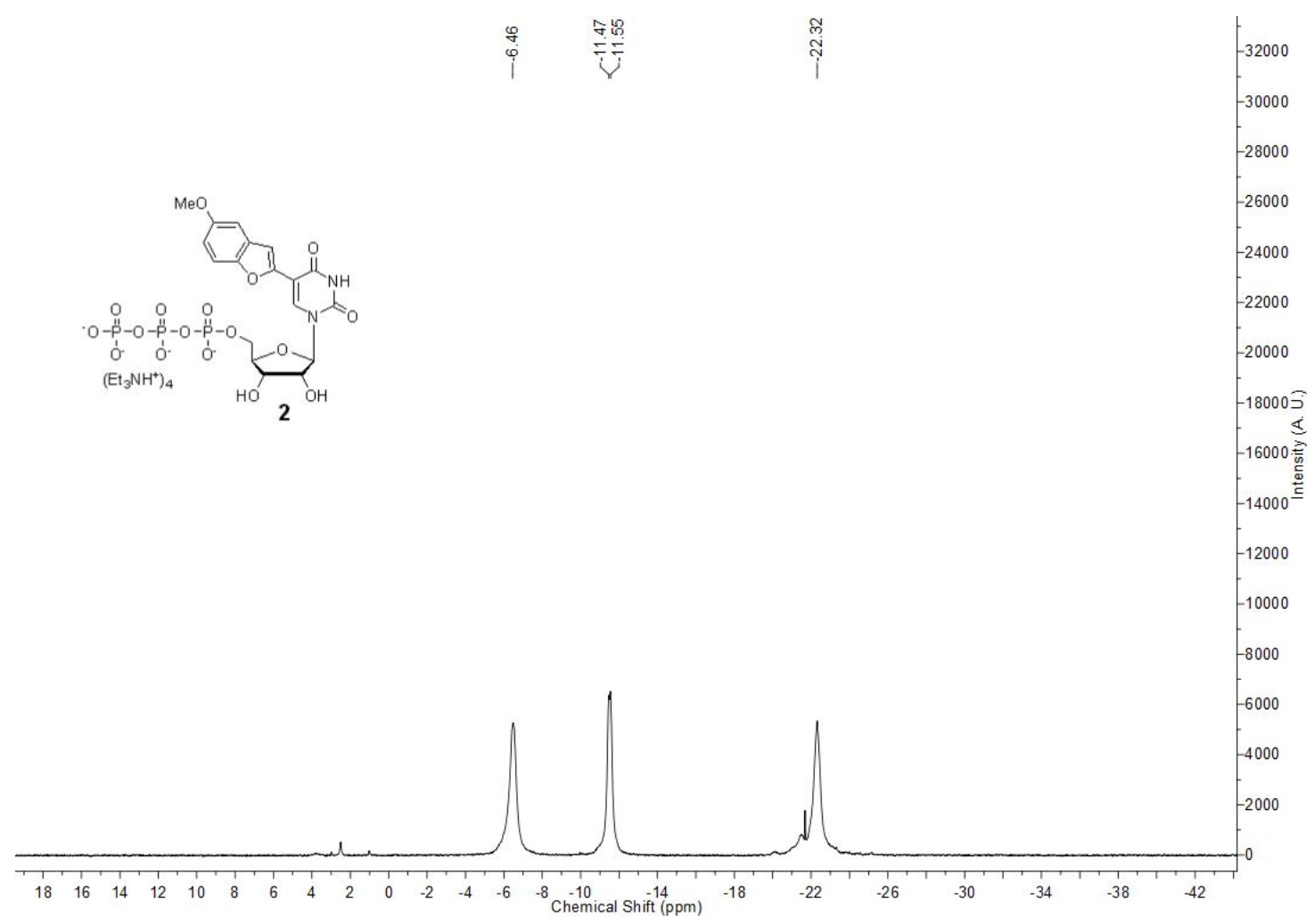

\section{References}

(S1) Bonini, C.; Cristiani, G.; Funicello, M.; Viggiani, L. Facile entry to 4- and 5hydroxybenzofuran and to their amino derivatives. Synth. Commun. 2006, 36, 1983-1990.

(S2) Shah, K.; Wu, H.; Rana, T. M. Synthesis of uridine phosphoramidite analogs: reagents for site-specific incorporation of photoreactive sites into RNA sequences Bioconjugate Chem. 1994, 5, 508-512.

(S3) Lavabre, D.; Fery-Forgues, S. Are fluorescence quantum yields so tricky to measure? a demonstration using familiar stationery products. J. Chem. Educ. 1999, 76, 1260-1264.

(S4) Pawar, M. G.; Nuthanakanti, A.; Srivatsan, S. G. Heavy atom containing fluorescent ribonucleoside analog probe for the fluorescence detection of RNA-ligand binding. Bioconjugate Chem. 2013, 24, 1367-1377.

(S5) Pawar, M. G.; Srivatsan, S. G. Synthesis, thermal stability, biophysical properties, and molecular modeling of oligonucleotides of RNA containing 2'-O-2-thiophenylmethyl groups. Org. Lett. 2011, 13, 1114-1117.

(S6) Tanpure, A. A.; Srivatsan, S. G. A Microenvironment-sensitive fluorescent pyrimidine ribonucleoside analogue: synthesis, enzymatic incorporation, and fluorescence detection of a DNA abasic site. Chem. Eur. J. 2011, 17, 12820-12827.

(S7) Tanpure, A. A.; Srivatsan, S. G. Conformation-sensitive nucleoside analogues as topologyspecific fluorescence turn-on probes for DNA and RNA G-quadruplexes. Nucleic Acids Res. 2015, 43, e149.

(S8) Schmidt, O. P.; Benz, A. S.; Mata, G; Luedtke, N. W. HgII binds to C-T mismatches with high affinity. Nucleic Acids Res. 2018, 46, 6470-6479. 